\title{
Production and Quality of Biscuits from Composite
}

\section{Flours}

\author{
ABDUlwAHAB ISMAIL DUROJAIYE ${ }^{1}$, L. G. Abubakar ${ }^{1}$, N. G. Nwachukwu ${ }^{2}$, A. Mohammed ${ }^{1}$ and A. S. \\ Ibrahim $^{1}$ \\ 1. Department of Agricultural and Bioresource Engineering, Abubakar Tafawa Balewa University, PMB 0248, Yelwa Campus \\ Bauchi, Bauchi State, Nigeria
}

2. Department of Agricultural Biotechnology, National Biotechnology Development Agency, Umar Musa Yar' Adua Express Way, Lugbe, Abuja FCT, PMB 5118, Wuse, Abuja, Nigeria

\begin{abstract}
Biscuits were produced from bambara nut, cowpea and wheat flour blends. This study was carried out to evaluate the effects of varying the proportions of these flours on the nutritional quality and general acceptability of the biscuits. Five blends of composite flours were prepared by mixing wheat, bambara nut and cowpea (WBC) flours in the proportions: $\mathrm{T}_{1}(90: 5: 5)$, $\mathrm{T}_{2}$ (80:10:10), $T_{3}(70: 15: 15), T_{4}(60: 20: 20), T_{5}(50: 25: 25)$ and 100\% whole wheat flour was used as the control ( $\left.T_{0}\right)$. Composite flours produced were subjected to functional and proximate analysis while the biscuits made from the flour blends were also subjected to sensory evaluation and proximate analysis. The use of composite flour for the production of biscuits from cowpea and bambara nut flours as supplement for the wheat flour has improved the nutritional contents of the biscuits with protein value being highest at mixing ratio $T_{5}$. The functional properties of the biscuits showed some significant differences $(p<0.05)$ when compared with whole wheat biscuits. The results showed that biscuits produced from $\mathrm{T}_{5}$ formulation with proximate composition of $11.87 \%$ moisture, $2.90 \%$ ash, $18.61 \%$ protein and $75.62 \%$ carbohydrate was selected as the best product.
\end{abstract}

Key words: Biscuits formulation, composite flour, wheat, cowpea, bambara nut.

\section{Introduction}

Biscuit is an important edible confectionary crisp product of wheat majorly consumed with tea by human especially children and used as weaning food for infants [1]. The primary ingredients used for the production of biscuit (wheat flour, butter, salt, baking powder, fortified milk, whole eggs, sugar and vanilla) are deficient in protein which could be enhanced by supplementing the wheat flour with more nutritional pods and other leguminous crops [2].

Biscuit is an essential food material usually sold in ready to serve form contributing valuable quantities of 20 ppm iron, $12 \mathrm{ppm}$ calcium, $100 \mathrm{ppm}$ protein, 20 ppm calories, $40 \mathrm{ppm}$ fibre and some of the

Corresponding author: ABDULWAHAB ISMAIL DUROJAIYE, M. Eng, Engr., research fields: food engineering and postharvest technology.
B-vitamins to our diet and daily food requirement [3].

Wheat flour used for the production of biscuits is insufficient in many regions of the world resulting in importation of the flour by regions with limit supplies [4]. There is therefore, a compelling need to develop an adequate substitute for wheat flour. This substitute should be readily available, cheap and capable of replacing wheat in functionality.

Bambara nut (Vigna subterranean L.) has been used by researchers as composite flour for baking because of its nutritional value. Bambara nut is high in protein that plays important role in human nutrition. Study shows that it contains $20-26 \%$ crude protein (high in lysine; 6.6\%); and makes an excellent source of supplementing proteins in the diet [5].

Bambara nut is consumed in many ways: in many West African Countries, the fresh pods are boiled with salt and pepper, roasted seed can be boiled, crushed 
and eaten as relish and eaten as a snack while in Cote d'Ivoire, the seed is used to make flour, which makes it more digestible. In East African, the beans are roasted, then pulverised, and used to make soup, with or without condiments while in Zambia used for the production of bread [6]. Other common uses of bambara nut are for the production of various fried or steamed products such as "akara" and "moimoi" in Nigeria. Bambara nut milk was examined along side with cowpea, pigeon pea and soybean and was ranked first while all other milks were found to be acceptable [6]. Adu-Dapaah and Sangwan [7] reported that the seed is regarded as a balanced food because when compared to most legumes, it is rich in iron and the protein contents high lysine and methonine and in addition it is known to contain $63 \%$ carbohydrate, $18 \%$ oil and fatty acid content is predominantly linoleic, palmitic and linolenic acids [8].

Cowpea is one of the most drought tolerant crops and has big potential as food security crop for many poor African subsistence farmers. Cowpea also has high quality proteins that could compete favourably with soyabean protein when substituted in diets at equivalent protein content [9, 10]. A limited number of studies have also demonstrated that cowpeas have high antioxidant capacity [11] and that the antioxidant properties may be improved by heat processing or fermentation [12]. Research evidence also suggests that whole cowpea is effective at binding cholesterol and lowering blood cholesterol in hamsters [13].

Cowpeas (Vigna unguicutala) are grown extensively in 16 African countries. Nigeria and Niger put together produced $49 \%$ of the world crop. Available data of Food and Agricultural Organisation [14] indicated that cowpea is a cash crop in Burkina Faso, Ghana, Nigeria, Mali, Mauritania, Niger and Senegal. Among these, Nigeria is the largest producer both in the West African sub-region and in the world at large. More than 2.5 million metric tonnes of cowpea are produced annually. Nigeria has unfavourable climate condition for wheat cultivation, but suitable for other cereals (sorghum, maize, millet and acha); legumes (soybean, groundnut, bambara nut, cowpeas) and vegetable [1]. Reports from International Institute for Tropical Agriculture (IITA) revealed that importation of wheat into the Country (Nigeria) amount to the tune of $\$ 40.7$ billion in recent time. This research however, aimed at improving the quality of biscuit based products by the addition of bambara nut and cowpea as supplement to wheat flour at varying ratio.

\section{Materials and Methods}

The wheat, cowpea and bambara nut seeds used for this study were purchased at Muda-Lawan market in Bauchi, Bauchi State, Nigeria. Other ingredients: granulated sugar $(1.25 \mathrm{~g})$, fortified milk $(15 \mathrm{~mL})$, baking powder (2.0 g), whole eggs (1.25 g), butter (33 g), salt $(0.2 \mathrm{~g})$ and vanilla (1.0 g) used in the production of the biscuits formulation were also obtained from the same market.

\subsection{Flour Preparation}

Bambara nut flour was prepared using the method described by Nwosu [5]. Bambara nut seeds were cleaned manually to remove all foreign materials such as dust, dirt, small branches and immature seeds. The cleaned sample were sorted and steeped in water for 12 hrs; it was then dehulled and oven dried using Genlab oven, at $60{ }^{\circ} \mathrm{C}$ for $3 \mathrm{hrs}$ and finely ground to powder $(0.60 \mathrm{~mm})$ form with a high speed grinding machine and sieved using $500 \mu \mathrm{m}$ sieve to obtain fine flour (Fig. 1).

Cowpea seeds were manually cleaned and sorted to remove the foreign materials. Totally, 1,304 g was measured. In preparing the flour, samples were soaked in water for 5 minutes after which it was dehulled manually to remove the coat, then water was decanted alongside the coats. It was allowed to drain off and then dried in the oven dryer at $40{ }^{\circ} \mathrm{C}$ for $3 \mathrm{hrs}$. The dried seeds were finely ground using milling machine and sieved to obtain the flour (Fig. 1).

\subsection{Biscuit Making}


The mixing ratios of the biscuit formulations were as presented in Table 1 while the biscuit was prepared

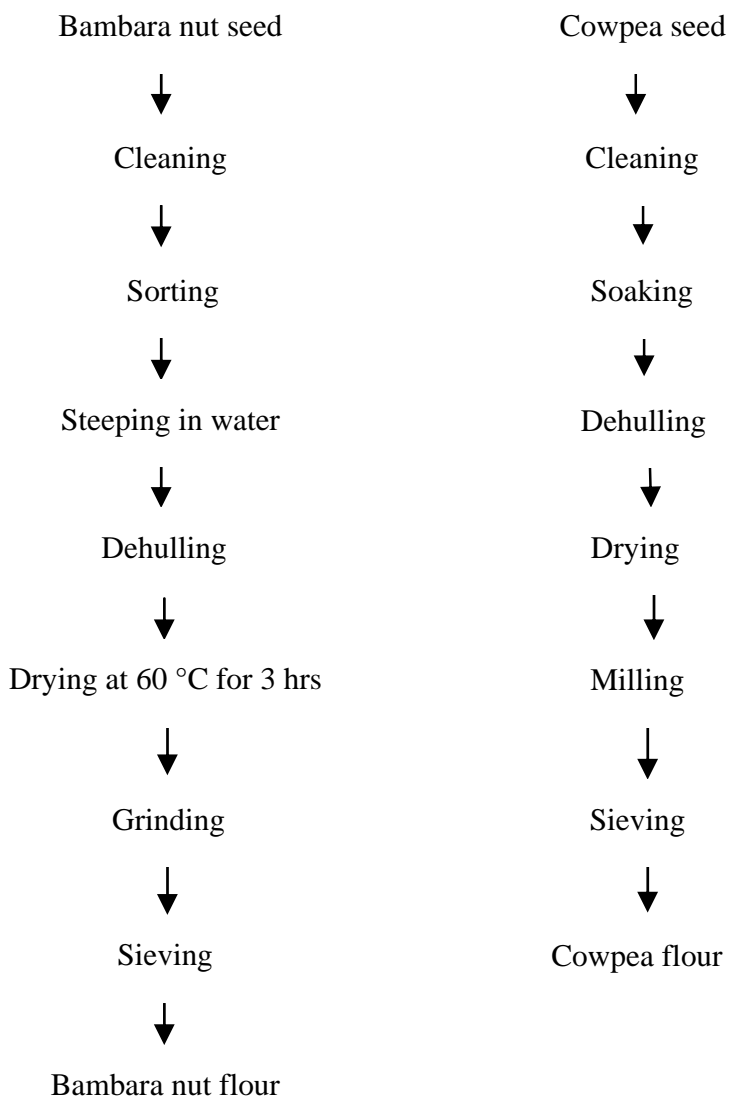

Fig. 1 Bambara nut and cowpea flour preparation [5].

Table 1 Composite flour compositions of wheat, bambara nut and cowpea.

\begin{tabular}{llll}
\hline Treatment & Wheat flour & Bambara nut flour & Cowpea flour \\
\hline $\mathrm{T}_{0}$ (Whole wheat flour as control) & 100 & 0 & 0 \\
$\mathrm{~T}_{1}$ (5\% bambara nut flour, 5\% cowpea flour) & 90 & 5 & 5 \\
$\mathrm{~T}_{2}$ (10\% bambara nut flour, 10\% cowpea flour) & 80 & 10 & 10 \\
$\mathrm{~T}_{3}(15 \%$ bambara nut flour, 15\% cowpea flour) & 70 & 15 & 15 \\
$\mathrm{~T}_{4}(20 \%$ bambara nut flour, 20\% cowpea flour) & 60 & 20 & 20 \\
$\mathrm{~T}_{5}$ (25\% bambara nut flour, 25\% cowpea flour) & 50 & 25 & 25 \\
\hline
\end{tabular}

using the method described by AOAC [15]. The flours (200 g), butter (33 g) and salt (0.2 g) were mixed together manually for $5 \mathrm{~min}$ to get a creamy dough. The baking powder $(2.0 \mathrm{~g})$, fortified milk $(15 \mathrm{~mL})$, whole eggs $(1.25 \mathrm{~mL})$, sugar (1.25 g), vanilla (1.0 g) were mixed thoroughly. And $65 \mathrm{~mL}$ of water was gradually added using continuous mixing until good texture, slightly firm dough is obtained. The dough was kneaded on a clean flat surface for 4 mins. It was manually rolled into sheets and cut into shapes using the stamp cutting method. The cut dough pieces were transferred into fluid fat grease pans and baked in an oven at $180{ }^{\circ} \mathrm{C}$ for $20 \mathrm{~min}$, cooled and packed for further analysis.

\subsection{Proximate Analyses of Wheat, Bambara Nut and Cowpea Flours.}

The wheat, bambara nut and cowpea flours were 
analyzed for moisture content, ash content, crude fibre, crude fat and crude protein as prescribed by the standard setup in Ref. [16]. Total carbohydrate was determined by simple difference method. Initial nutritional compositions of the three composite flours were determined in triplicates to evaluate effect of the treatment on the end product.

\subsection{Physical Analysis of Biscuits}

The diameter (width), thickness and spread factor of the biscuit product for each blend was determined as prescribed by Ayo et al. [17].

Spread factor is the ratio that depends on the values of the thickness and diameter of the biscuits. Spread factor (SF) was determined from the diameter and thickness using the formula:

$$
S F=\frac{D \times C F \times 10}{T}
$$

where, $C F$ is a correction factor at constant atmospheric pressure, $T=$ Thickness of biscuits $(\mathrm{mm})$, $D=$ Diameter of biscuits (mm) as its value was 1.0 in this case [17].

\subsection{Sensory Evaluation of Biscuits}

The biscuit formulations at the specified mixing ratios described in Table 5 were evaluated for quality and overall acceptability using 10 panelists; the sensory evaluation was carried out for colour, flavour, crispness, texture and overall acceptability (Table 5).

\subsection{Statistical Analysis}

The data obtained from this study were statistically evaluated using IBM SPSS 21.0 statistical tool while the mean significant differences of triplicate values were separated by Duncan Multiple range method using analysis of variance (ANOVA) at $p<0.05$.

\section{Results and Discussion}

The mean initial proximate compositions of bambara nut, cowpea and wheat flour are presented in Table 2. The results indicate that total carbohydrate contents of the flours at raw stage were significantly higher in wheat flour than bambara nut and cowpea flour with 52.50\%, 21.06\% and 15.82\% respectively; while bambara and cowpea flour were statistically higher in protein contents than wheat flour which are $43.40 \%, 57.02 \%$ and $21.4 \%$, respectively. Crude fat contents were higher in cowpea than bambara nut and wheat flour (Table 2).

The results of proximate compositions of biscuit products at varying mixing ratios of bambara nut, cowpea and wheat flour indicate that there are statistical significant differences in the output $(p<$ $0.05)$. However, crude protein contents were observed with high significant value of $18.61 \pm 0.01 \%$ at mixing ratio $\mathrm{T}_{5}$ (25\% bambara nut flour, 25\% cowpea flour and $50 \%$ wheat flour) as compared with the control $\left(\mathrm{T}_{0}\right)$ and other treatments (Table 3).

Table 2 Initial nutrient values of samples (bambara nut, cowpea and wheat) flour.

\begin{tabular}{llll}
\hline Parameter & Bambara nut & Cowpea & Wheat \\
\hline Moisture (\%) & $3.68 \pm 0.14$ & $3.84 \pm 0.29$ & $12.3 \pm 0.24$ \\
Ash (\%) & $8.41 \pm 0.37$ & $7.93 \pm 0.17$ & $3.68 \pm 0.43$ \\
Crude protein (\%) & $43.40 \pm 0.35$ & $57.02 \pm 0.43$ & $21.4 \pm 0.55$ \\
Crude fibre (\%) & $5.86 \pm 0.18$ & $6.08 \pm 0.21$ & $6.18 \pm 0.27$ \\
Crude lipid (\%) & $4.40 \pm 0.811$ & $4.820 \pm 0.19$ & $0.18 \pm 0.57$ \\
Carbohydrate value (\%) & $21.06 \pm 0.53$ & $15.82 \pm 0.21$ & $52.5 \pm 0.60$ \\
Calorific value (kcal) & $5,784.55 \pm 0.12$ & $6,260.10 \pm 0.52$ & $1,704 \pm 0.45$ \\
Ether extract (\%) & $17.59 \pm 0.23$ & $19.27 \pm 0.11$ & $15.01 \pm 0.63$ \\
Nitrogen & $6.94 \pm 0.51$ & $9.12 \pm 0.76$ & $3.43 \pm 0.42$ \\
Phosphorus & $14.62 \pm 0.34$ & $17.89 \pm 0.61$ & $0.146 \pm 0.71$ \\
Calcium & $2.63 \pm 0.62$ & $1.09 \pm 0.51$ & $0.104 \pm 0.51$ \\
\hline
\end{tabular}


Table 3 Chemical composition of biscuit products.

\begin{tabular}{|c|c|c|c|c|c|c|c|c|}
\hline Treatments & $\begin{array}{l}\text { Moisture } \\
\text { content (\%) }\end{array}$ & $\begin{array}{l}\text { Crude ash } \\
\text { (\%) }\end{array}$ & $\begin{array}{l}\text { Crude protein } \\
(\%)\end{array}$ & $\begin{array}{l}\text { Crude fat } \\
(\%)\end{array}$ & $\begin{array}{l}\text { Crude fibre } \\
(\%)\end{array}$ & $\begin{array}{l}\text { Carbohydrate } \\
\text { (\%) }\end{array}$ & $\mathrm{Ca}$ & $\mathrm{Na}$ \\
\hline$\overline{\mathrm{T}_{0}}$ & $8.57 \pm 0.06^{\mathrm{a}}$ & $1.97 \pm 0.00^{\mathrm{a}}$ & $13.11 \pm 0.00^{\mathrm{a}}$ & $1.89 \pm 0.00^{\mathrm{a}}$ & $2.98 \pm 0.01^{\mathrm{f}}$ & $81.03 \pm 0.03^{\mathrm{e}}$ & $0.04 \pm 0.00^{\mathrm{a}}$ & $0.04 \pm 0.00^{\mathrm{a}}$ \\
\hline $\mathrm{T}_{1}$ & $10.26 \pm 0.01^{\mathrm{b}}$ & $2.10 \pm 0.00^{\mathrm{b}}$ & $13.46 \pm 0.00^{\mathrm{b}}$ & $0.97 \pm 0.01^{b}$ & $2.24 \pm 0.01^{\mathrm{e}}$ & $81.24 \pm 0.01^{\mathrm{f}}$ & $0.05 \pm 0.00^{\mathrm{a}}$ & $0.04 \pm 0.00^{\mathrm{a}}$ \\
\hline $\mathrm{T}_{2}$ & $10.83 \pm 0.01^{\mathrm{c}}$ & $2.14 \pm 0.01^{\mathrm{c}}$ & $13.94 \pm 0.00^{c}$ & $1.05 \pm 0.01^{\mathrm{c}}$ & $2.02 \pm 0.01^{\mathrm{d}}$ & $80.86 \pm 0.21^{\mathrm{d}}$ & $0.05 \pm 0.00^{\mathrm{a}}$ & $0.04 \pm 0.00^{\mathrm{b}}$ \\
\hline $\mathrm{T}_{3}$ & $11.16 \pm 0.01^{\mathrm{d}}$ & $2.23 \pm 0.00^{\mathrm{d}}$ & 14.6 & $1.10 \pm 0.01^{\mathrm{d}}$ & $1.95 \pm 0.01^{\mathrm{C}}$ & $80.09 \pm$ & $0.0 €$ & $.00^{\mathrm{d}}$ \\
\hline $\mathrm{T}_{4}$ & $11.59 \pm 0.01^{\mathrm{e}}$ & $2.55 \pm 0.00^{\mathrm{e}}$ & $15.20 \pm 0.01^{\mathrm{e}}$ & $1.43 \pm 0.01^{\mathrm{e}}$ & $1.81 \pm 0.01^{\mathrm{b}}$ & $79.02 \pm 0.01^{b}$ & $0.24 \pm 0.18^{\mathrm{a}}$ & $0.05 \pm 0.00^{\mathrm{d}}$ \\
\hline $\mathrm{T}_{5}$ & $11.87 \pm 0.01^{\mathrm{f}}$ & $2.90 \pm 0.00^{f}$ & $18.61 \pm 0.01^{\mathrm{f}}$ & $1.96 \pm 0.01^{\mathrm{f}}$ & $1.44 \pm 0.01^{\mathrm{a}}$ & $75.62 \pm 0.03^{\mathrm{a}}$ & $0.07 \pm 0.00^{\mathrm{a}}$ & $0.06 \pm 0.00^{\mathrm{e}}$ \\
\hline
\end{tabular}

Values are mean $\pm \mathrm{SEM} ; \mathrm{T}_{0}=100 \%$ of whole wheat; $\mathrm{T}_{1}=90 \%$ of wheat, $5 \%$ of bambara nut and $5 \%$ of cowpea; $\mathrm{T}_{2}=80 \%$ of wheat, $10 \%$ of bambara nut and $10 \%$ of cowpea; $\mathrm{T}_{3}=70 \%$ of wheat, $15 \%$ of bambara nut and $15 \%$ of cowpea; $\mathrm{T}_{4}=60 \%$ of wheat, $20 \%$ of bambara nut and $20 \%$ of cowpea; $\mathrm{T}_{5}=50 \%$ of wheat, $25 \%$ of bambara nut and $25 \%$ of cowpea.

High crude protein value experienced in the sample could be a result of increase in bamara nut and cowpea flour proportion which concurs with previous finding of Ref. [18].

This is an indication that the $T_{5}$ blending ratio can effectively supplement biscuit production from wheatflour to improve the protein requirement by consumers. General trend of the results of biscuit products in this work also indicated that $\mathrm{T}_{5}$ consists of higher moisture content, crude ash, crude fat, crude fibre, calcium and sodium content as compared with other blending ratios (Table 3) but has least carbohydrate contents of $75.62 \pm 0.03 \%$. High ash content has been attributed to high minerals which invariably could increase the mineral content of the consumers and are good for the bones as reported by Agu et al. [19]. High values of crude fat content agree with the findings of Agu et al. [20] which can be improved on subsequently to serve as added advantage in improving product shelf stability alongside with observed high moisture content (11.87\%) although within acceptable limit in terms of food storage as recommended by USDA [20] which states $13-15 \%$ safe moisture contents as optimal range for storage of food and cereal grain. High value of fibre contents could also improve the digestion and aid waste elimination in the body and guide against anthracites [21]. Low value of carbohydrate content could be as result of initial low contents obtained in bambara nut (21.06 \pm 0.53$)$ and cowpea flour (15.82 \pm 0.21 ) value which actually increased significantly in the final biscuit product as compared with the initial value of wheat flour (52.5 \pm 0.60$)$ (Table 2).

\subsection{Physical Characteristics}

The effects of biscuit prepared from different mixing ratios of bambara nut, cowpea substituted wheat flour as control (100\% wheat flour) are shown in Table 4 while the physical characteristics of the product are shown in Fig. 2.

The spread ratio of the sample ranged from 51.45\% in $\mathrm{T}_{1}$ and $\mathrm{T}_{2}$ to $76 \%$ in $\mathrm{T}_{5}$ while the control $\left(\mathrm{T}_{0}\right)$ has $58 \%$. An increase the spread ratio could be as a result of relatively increase in oil contents contained in the

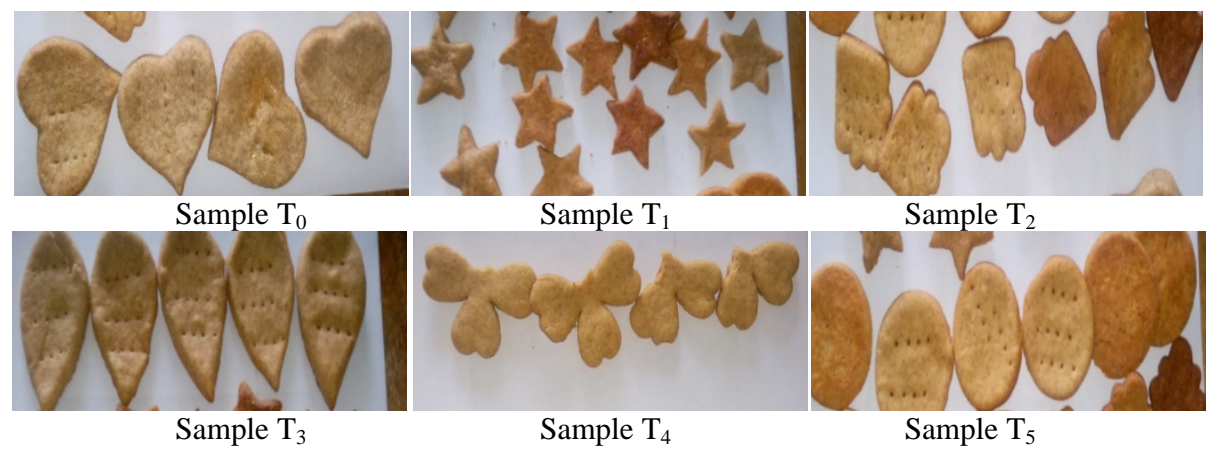

Fig. 2 Physical appearance of biscuit production from composite flours. 
Table 4 Physical characteristics of biscuits.

\begin{tabular}{llll}
\hline Sample & Thickness $(\mathrm{mm})$ & Diameter $(\mathrm{mm})$ & Spread factor \\
\hline $\mathrm{T}_{0}$ & 47.33 & 274.5 & 58.00 \\
$\mathrm{~T}_{1}$ & 38 & 195.5 & 51.45 \\
$\mathrm{~T}_{2}$ & 37.67 & 194 & 51.45 \\
$\mathrm{~T}_{3}$ & 50 & 315 & 63.00 \\
$\mathrm{~T}_{4}$ & 39.33 & 244 & 62.04 \\
$\mathrm{~T}_{5}$ & 40 & 304 & 76.00 \\
\hline
\end{tabular}

Table 5 Sensory attributes of composite biscuit from bambara nut, cowpea and wheat.

\begin{tabular}{|c|c|c|c|c|c|}
\hline Treatment & Colour & Flavour & Crispness & Texture & Overall acceptability \\
\hline$\overline{\mathrm{T}_{0}}$ & $4.93 \pm 0.03^{\mathrm{cd}}$ & $5.00 \pm 0.58^{\mathrm{abc}}$ & $5.00 \pm 0.58^{\mathrm{b}}$ & $5.33 \pm 0.33^{\mathrm{ab}}$ & $4.97 \pm 0.29^{\mathrm{a}}$ \\
\hline $\mathrm{T}_{1}$ & $4.30 \pm 0.35^{\mathrm{bc}}$ & $5.33 \pm 1.20^{\mathrm{bc}}$ & $3.00 \pm 0.58^{\mathrm{a}}$ & $5.27 \pm 0.54^{\mathrm{ab}}$ & $4.27 \pm 0.45^{\mathrm{a}}$ \\
\hline $\mathrm{T}_{2}$ & $5.8 \pm 0.76^{\mathrm{d}}$ & $5.97 \pm 0.29^{c}$ & $5.33 \pm 0.88^{\mathrm{bc}}$ & $6.23 \pm 0.23^{\mathrm{b}}$ & $7.00 \pm 0.58^{\mathrm{b}}$ \\
\hline $\mathrm{T}_{3}$ & $3.33 \pm 0.88^{\mathrm{ab}}$ & $3.20 \pm 0.17^{\mathrm{a}}$ & $4.00 \pm 0.58^{\mathrm{ab}}$ & $4.80 \pm 0.35^{\mathrm{a}}$ & $5.00 \pm 0.00^{\mathrm{a}}$ \\
\hline $\mathrm{T}_{4}$ & $3.05 \pm 0.03^{\mathrm{a}}$ & $3.80 \pm 0.15^{\mathrm{ab}}$ & $4.67 \pm 0.33^{\mathrm{ab}}$ & $4.83 \pm 0.17^{\mathrm{a}}$ & $4.67 \pm 0.17^{\mathrm{a}}$ \\
\hline $\mathrm{T}_{5}$ & $8.20 \pm 0.06^{\mathrm{e}}$ & $8.10 \pm 0.15^{\mathrm{d}}$ & $7.07 \pm 0.23^{\mathrm{bc}}$ & $8.20 \pm 0.31^{c}$ & $8.13 \pm 0.23^{c}$ \\
\hline
\end{tabular}

Values are means \pm SD of triplicate determinations. Values in the same column with different superscripts were significantly $(p<$ 0.05 ) different.

mixing ratio of bambara nut and cowpea flour which could enhance the attribute and added advantage as it will prevent breaking during post handling of the biscuit. The mean diameter of the biscuit product as shown in Table 4 indicates varying significant difference $(p<0.05)$. Data revealed that the highest was observed in biscuits prepared from $\mathrm{T}_{5}(304 \mathrm{~mm})$ whereas the lowest was observed in $\mathrm{T}_{2}(194 \mathrm{~mm})$. This is an indication that increase in the mixing formulation contributes to an increase in the size of the product, this conforms with the findings of Ref. [1]. Thickness of biscuit was found highest in the formulation with $\mathrm{T}_{3}$.

\subsection{Sensory Evaluation Results}

The results of the sensory evaluation of the biscuits produced from $\mathrm{T}_{5}$ (25\% bambara nut flour, $25 \%$ cowpea flour and $50 \%$ wheat flour) have overall acceptability while the quality of biscuits from $\mathrm{T}_{3}$ and $\mathrm{T}_{4}$ was rejected by the panellists (Table 5).

\section{Conclusion}

The study demonstrated use of composite flour for the production of biscuits from bambara nut and cowpea flours substituted for wheat flour which positively improved the nutrient contents of biscuits with high value in protein, crude fat, crude fibre. Increase in the carbohydrate content in $\mathrm{T}_{5}$ compared with initial value of wheat is also encouraging in term of balancing the vulnerable group diet. Overall acceptability of $\mathrm{T}_{5}$ is a justification for the recommendation of biscuits production at 25\% bambara nut flour, 25\% cowpea and 50\% wheat flour ratio which will enhance nutritional requirement for consumers and increase economic value of bambara nut and cowpea produce for possible application in the production of biscuit.

\section{References}

[1] Ferial, M. A., and Azza, A. A. 2011. "Effect of Supplementation on Bambara Ground Nut (Vigna subterranean L.) Flour on the Quality of Biscuits.” African Journal of Food Science 5 (7): 376-83.

[2] Yao, D. N., Kouassi, K. N., Erba, D., and Scazzina, F. 2015. "Expounding the Value of Grain Legumes in the Semi and Arid Tropics." International Journal of Agriculture 9 (1): 60.

[3] Barca de la, A. M. C., Rojas, M. E., and Islas, A. R. 2010. "Plant Foods for Human Nutrition." Journal Food and Nutrition 65 (5): 241-6.

[4] Zouari, R., Besbes, S., and Ellouze, S. 2016. "Cookies from Composite Wheat-Sesame Peels Flours; Dough Quality and Effect of Bacillus Subtilis SPB1 
Biosurfactant Addition.” Food Chemistry 194: 758-69.

[5] Nwosu, J. N. 2013. "Production and Evaluation of Biscuits from Blends of Bambara Groundnut and Wheat Flours.” International Journal of Food Nutri Science 2 (1): 4-9.

[6] Goli, A. E. 1995. "Bambara Groundnut (Vigna subterranean L.) Verdc.” Proceedings of the Workshop on Conservation and Improvement of Bambara Groundnut (Vigna subterranean (L.) Verdc), 14-6.

[7] Adu-Dapaah, H. K., and Sangwan, R. S. 2004. "Improving Bambara Groundnut Productivity Using Gamma Irradiation and Invitro Techniques.” African Journal of Biotechnology 3 (5): 260-5.

[8] Minka, S. R., and Bruneteau, M. 2000. "Partial Chemical Composition of Bambara Pea (Vigna subterranean (L) Verdc)." Food Chem. 68: 273-6.

[9] Obatuli, V. A., Ketiku, A., and Adebowale, E. A. 2003. "Effect of Feeding Maize/Legume Mixtures on Biochemical Indices in Rats. Ann.” Nutri. Metab. 47: 170-5.

[10] Aguirre, L. A., Savon, L., Santos, Y., and Dihigo, L. E. 2003. "Physiological Response in Rats Consuming Crude Cowpea (Vignaunguiculata) Grains Meal as Substitutes for Commercial Soybean. Blood Indices.” Cuban Journal of Agricultural Science 37: 33-5.

[11] Siddhuraju, P., and Becker, K. 2007. "The Antioxidant and Free Radical Scavenging Activities of Processed Cowpea (Vignaunguiculata (L.) Walp.) Seed Extracts.” Food Chem. 101: 10-9.

[12] Doblado, R., Zielinski, H., Piskula, M., Kozlowska, H., Munoz, R., Frias, J., and Vidal-Valverde, C. 2005. "Effectof Processing on the Antioxidant Vitamins and Antioxidant Capacity of Vignasinensis var. Carilla." Journal of Agric. Food Chem. 53: 1215-22.
[13] Frota, K. M. G., Mendonca, S., Saldiva, P. H. N., Cruz, R. J., and Areas, J. A. G. 2008. "Cholestrol-Lowering Properties of Whole Cowpea Seed and Its Protein Isolate in Hamsters.” Journal of Food Science 73: H235-40.

[14] Food and Agricultural Organisation. 2004. "Assessment of Fermentation as a Household Technology for Improving Food Safety.” Food Control 85 (60): 211-26.

[15] AOAC. 2002. Official Methods of Analysis of the Association of Chemists. Washington, DC: Analysis of the Association of Chemists.

[16] American Association of Cereals Chemists (AACC). 2000. "Approval Methods of American Association of Cereal Chemists.” International Journal of Food and Nutritional Science 14 (5): 99-203.

[17] Ayo, J. A., Ayo, V. A., Nkama, I., and Adewori, R. 2007. "Physicochemical Invitro Digestibility and Organoleptic Evaluation of Acha-wheat Biscuit Supplemented with Soybean Flour.” Nigerian Food Journal 25: 77-9.

[18] Boateng, M. A., Addo, J. K., Okyoro, H., Adu-Dapaah, H., Borohio, J. N., and Tottoh, A. 2013. "Physicochemical and Functional Properties of Groundnut (Vigna substerranean) Land Races.” African Journal of Food Science Technology 4 (4): 64-70.

[19] Agu, H. O., Ezeh, G. C., and Jideani, A. I. O. 2014. "Quality Assessment of Acha-based Biscuit Improved with Bambaranut and Unripe Plantain.” African Journal of Food Science 8 (5): 278-85.

[20] USDA. 2017. "US-Nigeria Commodity Storage Workshop VII-I on Stored grain Management in On-farm Storage and Warehouse Structures.” International Institute of Tropical Agriculture (IITA), Ibadan.

[21] Ayo, J. A., and Okoliko, A. 2003. "Effect of Spray Drying Temperature of Egg White Powder on the Quality of Meringue.” Journal of Arid Agriculture 13: 181-7. 